\title{
Poly(vinyl chloride) Ionic Liquid Polymer Electrolyte Based on Bis(fluorosulfonyl)Amide for Sodium Secondary Batteries
}

\section{$\operatorname{AUTHOR}(\mathrm{S}):$}

Rani, Mohd Azri Ab; Hwang, Jinkwang; Matsumoto, Kazuhiko; Hagiwara, Rika

\section{CITATION:}

Rani, Mohd Azri Ab ... [et al]. Poly(vinyl chloride) Ionic Liquid Polymer Electrolyte Based on Bis(fluorosulfonyl)Amide for Sodium Secondary Batteries. Journal of The Electrochemical Society 2017, 164(8): H5031-H5035

\section{ISSUE DATE:}

2017-05-03

URL:

http://hdl.handle.net/2433/224951

\section{RIGHT:}

(c) The Author(s) 2017. Published by ECS. This is an open access article distributed under the terms of the Creative Commons Attribution 4.0 License (CC BY, http://creativecommons.org/licenses/by/4.0/), which permits unrestricted reuse of the work in any medium, provided the original work is properly cited. 


\title{
Poly(vinyl chloride) Ionic Liquid Polymer Electrolyte Based on Bis(fluorosulfonyl)Amide for Sodium Secondary Batteries
}

\author{
Mohd Azri Ab Rani, ${ }^{\text {a,b,z }}$ Jinkwang Hwang, ${ }^{a}$ Kazuhiko Matsumoto, ${ }^{\text {a,* }}$ and Rika Hagiwara ${ }^{\text {a,* }}$ \\ ${ }^{a}$ Graduate School of Energy Science, Kyoto University, Yoshida, Sakyo-ku, Kyoto 606-8501, Japan \\ ${ }^{b}$ Faculty of Applied Sciences, Universiti Teknologi MARA, 40450 Shah Alam, Selangor, Malaysia
}

\begin{abstract}
Non-flammable electrolytes have been extensively studied to improve the safety of energy storage devices. In this study, a new ionic liquid polymer electrolyte (ILPE) prepared by a cast technique using poly(vinyl chloride) (PVC) as the host polymer was examined for sodium secondary batteries. The ILPE containing $50 \mathrm{wt} \%$ of 1-ethyl-3-methylimidazolium bis(fluorosulfonyl)amide $\left[\mathrm{C}_{2} \mathrm{C}_{1} \mathrm{im}\right][\mathrm{FSA}]$ ionic liquid showed an ionic conductivity of $5.6 \mathrm{mS} \mathrm{cm}^{-1}$ at $318 \mathrm{~K}$. It remains stable up to $517 \mathrm{~K}$ based on $5 \mathrm{wt} \%$ loss. Stable sodium metal electrodeposition/dissolution was observed at the cathodic limit of the electrochemical window for the ILPE containing $\mathrm{Na}[\mathrm{FSA}]\left(\left[\mathrm{C}_{2} \mathrm{C}_{1}\right.\right.$ im] $\left.[\mathrm{FSA}]: \mathrm{Na}[\mathrm{FSA}]: \mathrm{PVC}=2.0: 1.0: 1.0 \mathrm{w} / \mathrm{w}\right)$. The anodic limit was observed at around $4.7 \mathrm{~V}$ vs. $\mathrm{Na}^{+} / \mathrm{Na}$ on a Pt working electrode, while on an $\mathrm{Al}$ working electrode a higher anodic stability owing to passivation was observed. In the $\mathrm{Na} /\left[\mathrm{C}_{2} \mathrm{C}_{1} \mathrm{im}\right][\mathrm{FSA}]-\mathrm{Na}$ [FSA]-PVC/- $\mathrm{Na}_{2} \mathrm{FeP}_{2} \mathrm{O}_{7}$-cell with the theoretical capacity of $97 \mathrm{mAh} \mathrm{g}^{-1}$, a reversible capacity of 92 mAh g ${ }^{-1}$ was obtained at $363 \mathrm{~K}$ for the $\mathrm{Na}_{2} \mathrm{FeP}_{2} \mathrm{O}_{7}$ positive electrode. These results suggest great potential of this PVC-based ILPE for constructing very safe sodium secondary batteries.

(c) The Author(s) 2017. Published by ECS. This is an open access article distributed under the terms of the Creative Commons Attribution 4.0 License (CC BY, http://creativecommons.org/licenses/by/4.0/), which permits unrestricted reuse of the work in any medium, provided the original work is properly cited. [DOI: 10.1149/2.0221708jes] All rights reserved.

(cc) BY

Manuscript submitted February 13, 2017; revised manuscript received April 20, 2017. Published May 3, 2017. This was Paper 3500 presented at the Honolulu, Hawaii, Meeting of the Society, October 2-7, 2016. This paper is part of the JES Focus Issue on Progress in Molten Salts and Ionic Liquids.
\end{abstract}

Lithium secondary batteries are used in various applications such as portable electronics, consumer electronics, and auto motives. ${ }^{1,2}$ However, the uneven distribution of lithium resources might limit their feasibility in large scale energy storage systems. Consequently, sodium secondary batteries have become one of the most promising alternatives to lithium secondary batteries. ${ }^{3}$ The key advantages of using sodium-based energy storage devices are the low cost, and the abundant resources and low redox potential of sodium $\left(E^{\mathrm{o}} \mathrm{Na}^{+} / \mathrm{Na}=\right.$ -2.71 vs. SHE; which is $\sim 0.3 \mathrm{~V}$ higher than ${E^{\circ}}_{\mathrm{Li}^{+} / \mathrm{Li}}$ ).

While organic electrolytes are currently used in researching sodium secondary batteries, ${ }^{4,5}$ ionic liquids (ILs) offer great advantages in terms of safety, such as low vapor pressure, low flammability, high thermal stability, high conductivity, and wide electrochemical window. ${ }^{6,7}$ The physical and electrochemical properties of ILs in $\mathrm{Na}$ secondary batteries have been studied in recent works. ${ }^{8-12}$ In real application, polymerization of the IL is one important technique to retain the advantages of ILs and avoid leakage. As a type of gel polymer electrolytes (GPE), the resulting "ionic liquid polymer electrolytes (ILPEs)" consists of ILs, the host polymer, and another component for electrochemical reactions (e.g alkali metal salt). ${ }^{13,14}$ In ILPE, it is assumed that the IL phase is trapped within the polymer matrix, forming a self-standing polymer electrolyte with the ions moving in the liquid phase. The advantages of ILPE are high processability, high flexibility, and high dimensional stability that lead to the elimination of the separator. In comparison with the conventional separator, ILPE offers better capacity to trap liquid electrolytes, ${ }^{15}$ and acts as the separator and electrolyte at the same time.

One of the most challenging issues for ILPEs is improving the compatibility among the IL, the host polymer, and the third component (e.g. alkali metal salt). Most studies of ILPE for lithium secondary batteries are based this ternary system; using poly(ethylene oxide) (PEO) as a host polymer. ${ }^{16-21}$ For sodium ion conducting ILPE, only a few candidate host polymers have been demonstrated, including poly(vinylidene difluoride) ( $\mathrm{PVdF}$ ) and poly(vinylidene fluoridehexafluoropropylene) (PVdF-HFP). ${ }^{22,23}$ Very recent research also focused on PEO-based ILPEs for sodium secondary batteries. ${ }^{24-27}$ From the fundamental viewpoint, compared to the case of $\mathrm{Li}^{+}$-based polymer electrolytes, a weaker interaction between $\mathrm{Na}^{+}$and the host poly-

*Electrochemical Society Member.

${ }^{\text {z} E-m a i l: ~ a z r i @ s a l a m . u i t m . e d u . m y ~}$ mer and the weaker ion-ion interaction may result in more efficient creation and transport of $\mathrm{Na}^{+}$ions as the charge carrier. ${ }^{28}$

Our recent reports showed the high potential of IL electrolytes for sodium secondary batteries in combination with various electrode materials especially at elevated temperatures., ${ }^{8,29-33}$ For secondary batteries, operation at elevated temperatures is preferable with the aid of thermally and chemically stable IL electrolytes, in many environments (such as the engine compartments of automobiles) that are constantly heated by waste heat from devices or machines. Sodium iron pyrophosphate, $\left(\mathrm{Na}_{2} \mathrm{FeP}_{2} \mathrm{O}_{7}\right.$ theoretical capacity: $\left.97 \mathrm{mAh} \mathrm{g}^{-1}\right)$, which is composed of naturally abundant elements $\mathrm{Na}, \mathrm{Fe}$ and $\mathrm{P}$ is an attractive positive electrode material with three-dimensional diffusion path of $\mathrm{Na}^{+} .{ }^{34-38}$ Particularly, it is known to provide high rate performance in the IL system of Na[FSA]$\left[\mathrm{C}_{2} \mathrm{C}_{1} \mathrm{im}\right][\mathrm{FSA}]\left(\mathrm{FSA}^{-}=\right.$bis(fluorosulfonyl)amide and $\left(\mathrm{C}_{2} \mathrm{C}_{1} \mathrm{im}^{+}=\right.$ 1-ethyl-3-methylimidazolium cation). ${ }^{39}$

The present study reports the physicochemical and electrochemical properties of the new ILPE system of $\mathrm{Na}[\mathrm{FSA}]-\left[\mathrm{C}_{2} \mathrm{C}_{1}\right.$ im] [FSA]PVC ( $\mathrm{PVC}=$ poly (vinyl chloride) $)$ including the charge-discharge behavior of the $\mathrm{Na}_{2} \mathrm{FeP}_{2} \mathrm{O}_{7}$ positive electrode. Among the few reports of using PVC as a host polymer for ILPEs, Deraman et al. studied the conductivity and electrochemical properties of PVC doped with ammonium triflate IL. ${ }^{40}$ Recently, another group tested PVC as a host polymer for two types of phosphonium ILs, $\left[\mathrm{P}_{14,6,6,6}\right][\mathrm{Cl}]$ and $\left[\mathrm{P}_{14,6,6,6}\right]\left[\mathrm{NTf}_{2}\right]\left(\mathrm{P}_{14,6,6,6}{ }^{+}=\right.$trihexyltetradecylphosphonium cation $),{ }^{41}$ and characterized the chemical, morphological, thermomechanical, and electric properties of the resulting ILPE. The influence of ionicity of the phosphonium IL on the ionic conductivity of the PVC-based electrolyte and the thermomechanical properties of PVC was also reported in the same study. Compared to these previous studies, here we present the first report using PVC as a host polymer in ILPE based on bis(fluorosulfonyl)amide ILs for sodium secondary batteries.

\section{Experimental}

Materials.-The air sensitive materials were handled in a glove box under a dry deoxygenated argon atmosphere. The salts, Na[FSA] (Mitsubishi Materials Electronic Chemicals, water content $<30 \mathrm{ppm}$ ) and $\left[\mathrm{C}_{2} \mathrm{C}_{1} \mathrm{im}\right][\mathrm{FSA}]$, (Kanto Chemical, water content $<30 \mathrm{ppm}$ ) were purchased and vacuum-dried at $353 \mathrm{~K}$ prior to use. The analytical grade PVC (average $\mathrm{M}_{w} 85,000$, Fluka) was used as received. 
Table I. Composition of the $\left[\mathrm{C}_{2} \mathrm{C}_{1}\right.$ im] $[\mathrm{FSA}]-\mathrm{Na}[\mathrm{FSA}]-\mathrm{PVC}$ ILPE samples.

\begin{tabular}{|c|c|c|c|c|}
\hline & \multicolumn{3}{|c|}{ Weight ratio } & \multirow{2}{*}{$\begin{array}{c}\text { Fraction of } \\
{\left[\mathrm{C}_{2} \mathrm{C}_{1} \text { im }\right][\mathrm{FSA}](\mathrm{wt} \%)}\end{array}$} \\
\hline & {$\left[\mathrm{C}_{2} \mathrm{C}_{1} \mathrm{im}\right][\mathrm{FSA}]$} & $\mathrm{Na}[\mathrm{FSA}]$ & PVC & \\
\hline ILPE-1 & 0 & 1.0 & 1.0 & 0 \\
\hline ILPE-2 & 0.5 & 1.0 & 1.0 & 20.0 \\
\hline ILPE-3 & 1.0 & 1.0 & 1.0 & 33.3 \\
\hline ILPE-4 & 1.5 & 1.0 & 1.0 & 42.9 \\
\hline ILPE-5 & 2.0 & 1.0 & 1.0 & 50.0 \\
\hline
\end{tabular}

Tetrahydrofuran (THF, Wako Chemicals) was used as supplied. Sodium iron pyrophosphate, $\mathrm{Na}_{2} \mathrm{FeP}_{2} \mathrm{O}_{7}$, was synthesized according to the previous report. ${ }^{39}$

Preparation of ILPE.-The ILPE films were prepared by a solution casting technique. PVC $(1 \mathrm{~g})$ was dissolved in $40 \mathrm{~mL}$ of THF, and the mixture was stirred vigorously until a clear homogenous solution was formed. The two salts of $\left[\mathrm{C}_{2} \mathrm{C}_{1} \mathrm{im}\right][\mathrm{FSA}]$ and $\mathrm{Na}[\mathrm{FSA}]$, in appropriate ratios (see Table $\mathrm{I}$ ) were added into the solution, and stirred at room temperature for 24 hours until a transparent and homogenous solution was formed. The viscous solution was cast into a petri dish and left in open air to allow the THF to evaporate. The film was then dried under vacuum at $333 \mathrm{~K}$ for 48 hours to form the flexible and self-standing polymer electrolyte. All films were stored in the glove box until analysis. Attempt to prepare ILPE with a higher content of $\left[\mathrm{C}_{2} \mathrm{C}_{1} \mathrm{im}\right][\mathrm{FSA}] \mathrm{IL}$ ( $>50 \mathrm{wt} \%$ ) resulted in segregation of the IL phase, and the film was not self-standing.

Analysis.-The ionic conductivity $(\sigma)$ of the synthesized ILPEs was measured by an impedance analyzer (3520-80, Hioki E.E. Corp). The ILPE was placed between a pair of stainless steel blocking electrodes. The data were collected in the frequency range between 1.0 $\times 10^{6}$ and $4.0 \mathrm{~Hz}$ with the amplitude of $10 \mathrm{mV}$ at the open circuit potential. $\sigma$ was calculated from the resistance of the bulk value $\left(R_{b}\right)$ found in the complex impedance diagram according to Eq. 1:

$$
\sigma=\frac{d}{R_{b} A}
$$

The ILPE was punched into a disk with the electrode area $(A)$ of $0.4 \mathrm{~cm}^{2}$. Its thickness $(d)$ was measured to be $\sim 0.45 \mathrm{~mm}$. Thermal decomposition of the ILPEs was analyzed by a Netzsch thermogravimetric analyzer (STA409EP) from 308 to $823 \mathrm{~K}$ under dry nitrogen flow at a heating rate of $5 \mathrm{~K} \mathrm{~min}^{-1}$. Scanning electron microscopy (SEM) (Cambridge, Leica) was used to observe the morphology of the samples. For cross sectional views, the sample was immersed in liquid nitrogen for $180 \mathrm{~s}$ and mechanically divided into pieces. Differential scanning calorimetric (DSC) measurements were carried out on a DSC-8230 Thermo Plus EVO II Series (Rigaku) instrument under a nitrogen atmosphere. Samples were hermetically sealed in $\mathrm{Al}$ cells in a glove box and then heated from 233 to $423 \mathrm{~K}$ at a heating rate of $5 \mathrm{~K} \mathrm{~min}{ }^{-1}$. Cyclic voltammetry was performed in a two-electrode cell (2032-type coin cell), with the ILPE placed between $\mathrm{Cu}, \mathrm{Al}$ or $\mathrm{Pt}$ working electrodes and the $\mathrm{Na}$ counter electrode. Charge-discharge test of the $\mathrm{Na} / \mathrm{ILPE} / \mathrm{Na}_{2} \mathrm{FeP}_{2} \mathrm{O}_{7}$ cell was performed with a Bio-Logic VSP potentiostat or a Hokuto Denko chargedischarge unit (HJ1001SD8) using 2032-type coin cells assembled in an $\mathrm{Ar}$-filled glove box. The positive electrode was prepared by mixing $\mathrm{Na}_{2} \mathrm{FeP}_{2} \mathrm{O}_{7}$, acetylene black (AB) as a conductive additive, and polytetrafluoroethylene (PTFE) as a binder in a weight ratio of 75:20:5. The resulting sheet typically has a thickness of $\sim 10 \mu \mathrm{m}$, and pressed on $\mathrm{Al}$ current collector. The Na metal disc was used as negative electrode (Aldrich, purity $99.95 \%$ ) and pressed onto $\mathrm{Al}$ current collector. The $\mathrm{Na}_{2} \mathrm{FeP}_{2} \mathrm{O}_{7}$ electrode was impregnated with the ILPE in the form of THF solution prior to the cell construction, and the THF solvent was removed under vacuum.

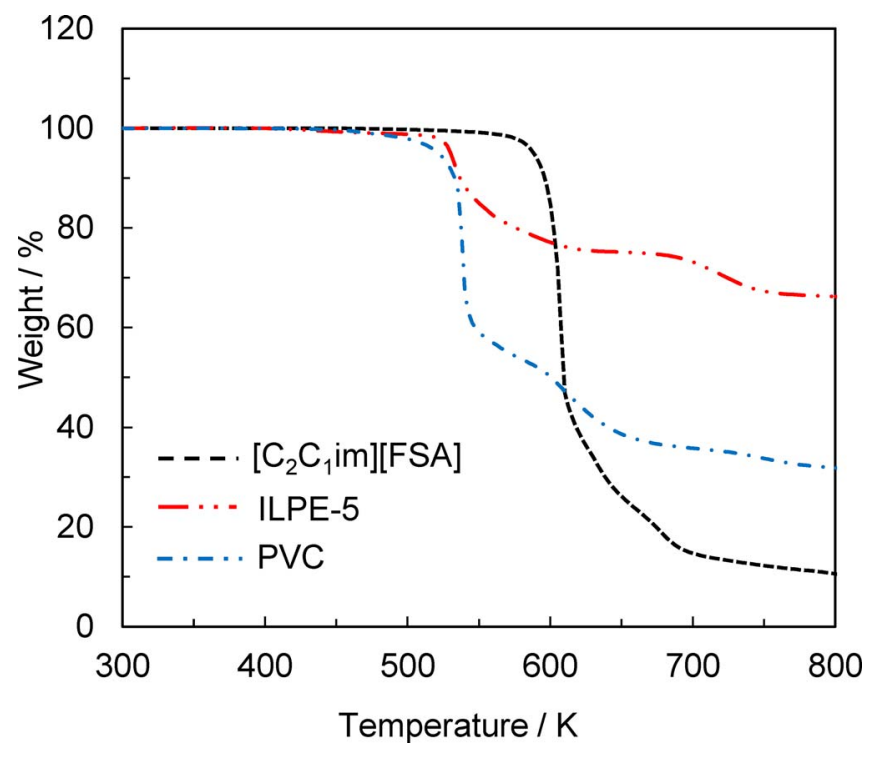

Figure 1. Thermogravimetric curves of ILPE-5, pure PVC, and the $\left[\mathrm{C}_{2} \mathrm{C}_{1} \mathrm{im}\right][\mathrm{FSA}]$ ionic liquid. Scan rate: $10 \mathrm{~K} \mathrm{~min}^{-1}$.

\section{Results and Discussion}

Thermal behavior.-Figure 1 shows thermogravimetric curves for ILPE-5 (the sample with the highest IL ratio), PVC polymer, and $\left[\mathrm{C}_{2} \mathrm{C}_{1}\right.$ im] $\left.] \mathrm{FSA}\right]$ IL. The decomposition temperature of ILPE-5 reached up to $517 \mathrm{~K}$ based on the $5 \mathrm{wt} \%$ loss criterion. The thermal stability of the ILPE depends on the PVC polymer, since the IL used here is more stable than the host polymer. The ILPE has sufficient thermal stability for the battery tests in the present study below $373 \mathrm{~K}$.

In comparison with ILPEs using other host polymers such as $\mathrm{PEO}^{25}$ or PVdF-HFP, ${ }^{42,43}$ the PVC-based ILPEs did not display any firstorder phase transition in the temperature between 298 and $423 \mathrm{~K}$ according to the DSC measurements, suggesting that the IL phase remains a liquid within the host polymer network, and that the PVC host polymer retains its form. The same behavior has been observed for methyl cellulose (MC)-based polymer electrolyte. ${ }^{44}$

Ionic conductivity.-Figure 2 shows the Arrhenius plots of ionic conductivities for the ILPEs in the temperature range between 298 and $363 \mathrm{~K}$. The ionic conductivity increases with increasing amount of IL, a trend that is in good agreement with a previous study of the ILPE containing $N$-butyl- $N$-methylpyrrolidinium bis(trifluoromethylsulfonyl)amide $\left(\left[\mathrm{C}_{4} \mathrm{C}_{1}\right.\right.$ pyrr][TFSA $]$ ) for lithium ion batteries. ${ }^{43}$ The sample ILPE-1 (0 wt \% IL) shows the lowest conductivity of $5.26 \times 10^{-6} \mathrm{mS} \mathrm{cm}{ }^{-1}$, at $318 \mathrm{~K}$, suggesting this system does not work without IL. The addition of the IL is believed to weaken the interaction between the polymer chains and hence enhance movements of the ions in the matrix. The sample with $50 \mathrm{wt} \%$ IL (ILPE-5) displayed the maximum ionic conductivity of $1.69 \mathrm{mS} \mathrm{cm}^{-1}$ at $298 \mathrm{~K}$. The 1.0:2.0 weight ratio of $\mathrm{Na}[\mathrm{FSA}]$ and $\left[\mathrm{C}_{2} \mathrm{C}_{1}\right.$ im] $]$ FSA $]$ in ILPE-5 corresponds to the molar ratio of $0.42: 0.58$. The ionic conductivity of the $\mathrm{Na}[\mathrm{FSA}]-\left[\mathrm{C}_{2} \mathrm{C}_{1} \mathrm{im}\right][\mathrm{FSA}]$ binary IL system at this ratio is 2.6 $\mathrm{mS} \mathrm{cm} \mathrm{cm}^{-1}$ at $298 \mathrm{~K}$ by linear approximation from a previous work. ${ }^{10}$ Comparison of these two values suggests that the ionic conductivity is reduced to $65 \%$ when the IL is packed into the polymer electrolyte. According to previous report, ${ }^{39}$ the transport number of $\mathrm{Na}^{+}$in the $\mathrm{Na}[\mathrm{FSA}]-\left[\mathrm{C}_{2} \mathrm{C}_{1}\right.$ im] [FSA] was 0.27 . By multiplying this value by $1.69 \mathrm{mS} \mathrm{cm}^{-1}$, the $\mathrm{Na}^{+}$ion conductivity in ILPE-5 is estimated to be $0.46 \mathrm{mS} \mathrm{cm}^{-1}$ at $298 \mathrm{~K}$ under the assumption that the transport number does not change in the ILPE. Because of its high ionic conductivity, ILPE-5 is used for further electrochemical analysis below. 


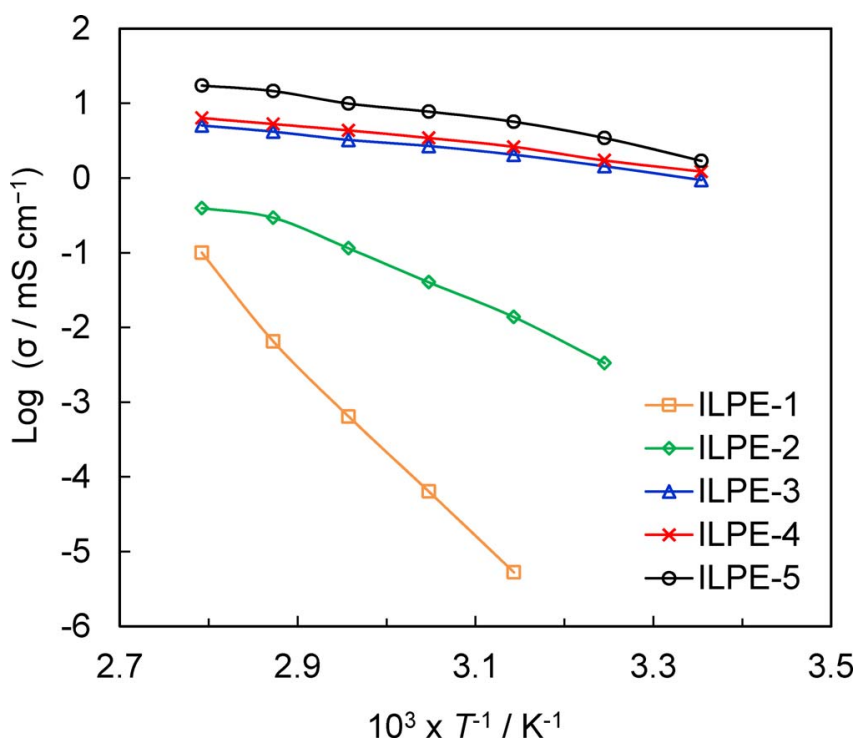

Figure 2. Arrhenius plots of ionic conductivity of the ILPEs with different ratios of $\left[\mathrm{C}_{2} \mathrm{C}_{1} \mathrm{im}\right][\mathrm{FSA}]$ ionic liquid in the temperature range between 298 and $363 \mathrm{~K}$.
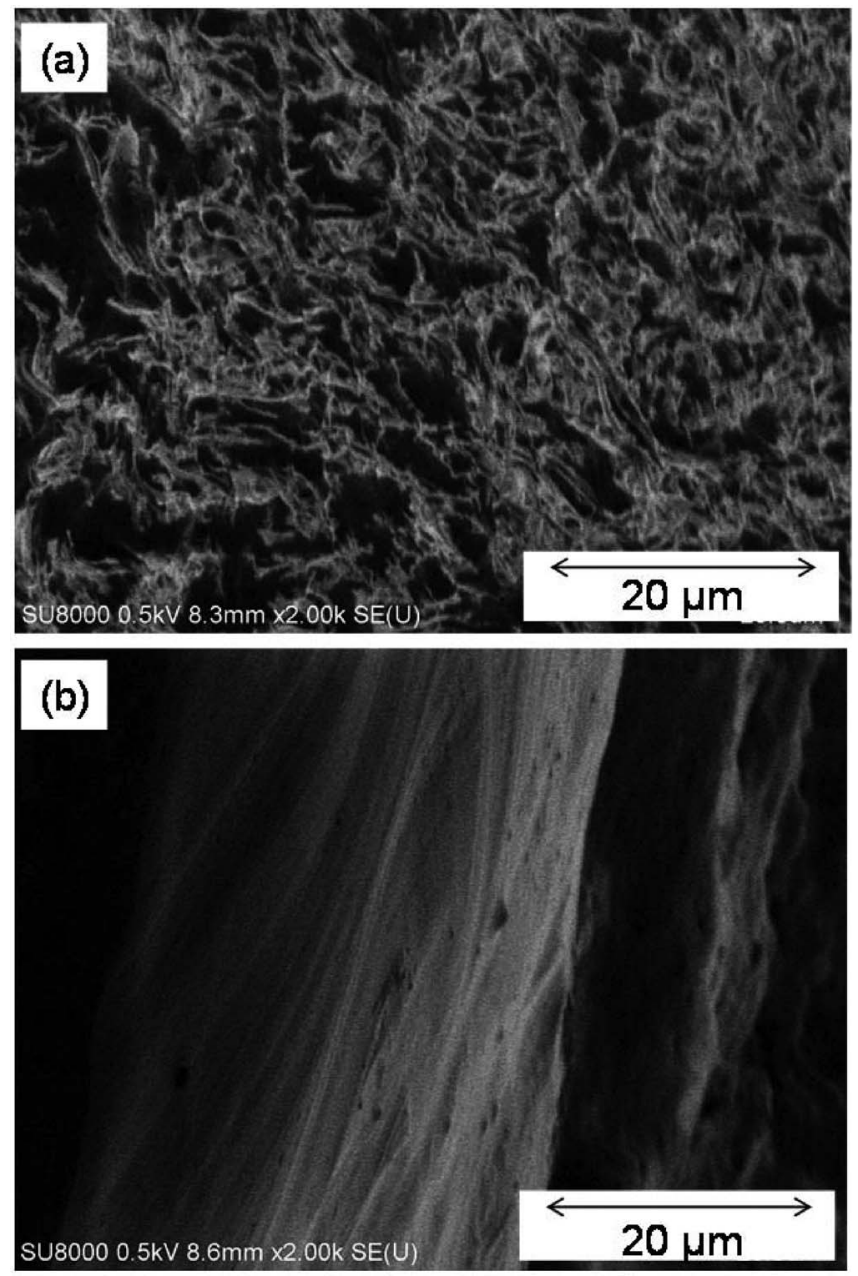

Figure 3. (a) Surface and (b) cross sectional SEM images of ILPE-5.

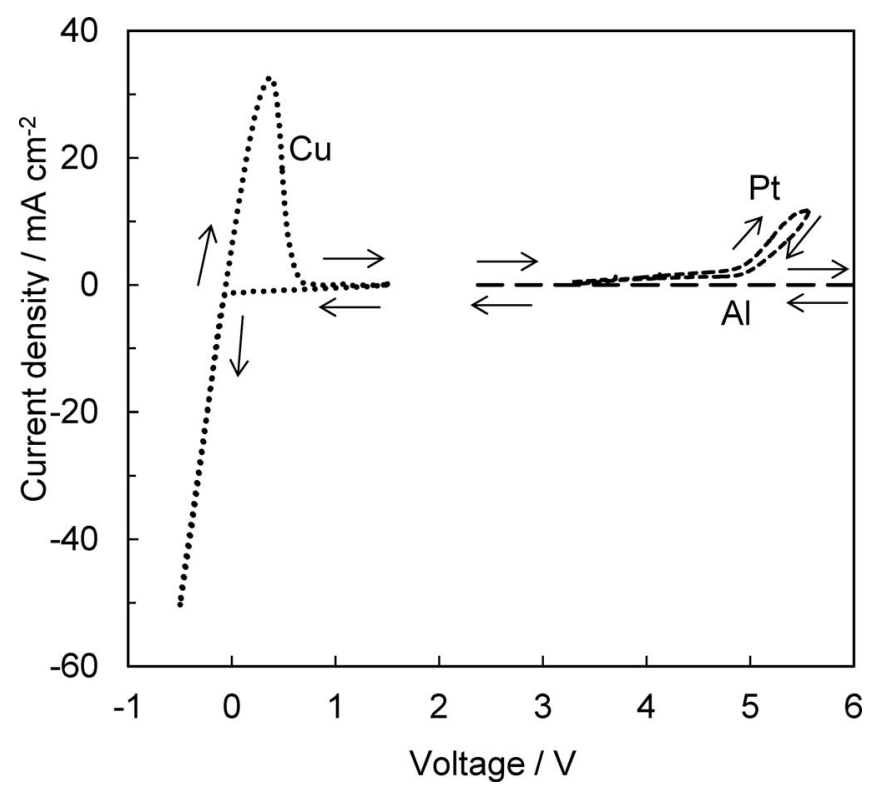

Figure 4. Cyclic voltammograms of $\mathrm{Cu}$ (negative potential region), $\mathrm{Pt}$ (positive potential region), and $\mathrm{Al}$ (positive potential region) plate electrodes at 363 $\mathrm{K}$ with the ILPE-5 electrolyte. The two-electrode test cell was used with the $\mathrm{Na}$ metal counter electrode. Scan rate: $5 \mathrm{mV} \mathrm{s}^{-1}$.

SEM image.-Figure 3 shows the surface and cross sectional SEM images of the ILPE-5 film. SEM observation of the ILPE sample without any special pretreatment is possible owing to the low vapor pressure of the ILs. The surface of the ILPE-5 film was rough and some inhomogeneity was observed. On the other hand, no obvious porous structure was observed in the cross sectional view suggesting homogenous impregnation of the $\mathrm{Na}[\mathrm{FSA}]-\left[\mathrm{C}_{2} \mathrm{C}_{1} \mathrm{im}\right][\mathrm{FSA}] \mathrm{IL}$ into the host polymer. The inhomogeneity at the surface is attributed to the removal of the solvent, and it does not extend to the interior. A similar observation has been reported for other ILPEs. ${ }^{42,44,45}$

Electrochemical window.-Figure 4 shows the cyclic voltammograms of $\mathrm{Cu}$ (negative potential region), $\mathrm{Pt}$ (positive potential region), and $\mathrm{Al}$ (positive potential region) plate electrodes with the ILPE-5 electrolyte at $363 \mathrm{~K}$. For the $\mathrm{Na}$ [FSA]- $\left[\mathrm{C}_{2} \mathrm{C}_{1}\right.$ im] [FSA] IL system, it was reported that $\mathrm{Na}$ metal deposition/dissolution occurs at $0 \mathrm{~V}$ vs. $\mathrm{Na}^{+} / \mathrm{Na} .{ }^{10}$ In this experiment, the cyclic voltammogram indicates that $\mathrm{Na}$ metal deposition/dissolution occurs for ILPE-5 at the cathodic limit with the Coulombic efficiency of $57 \%$. It should be noted this electrochemical reaction occurs at around $-0.1 \mathrm{~V}$ vs. the $\mathrm{Na}$ metal counter electrode under the present condition. Although the deposition overpotential is observed, the dissolution should occur at or above the $\mathrm{Na}^{+} / \mathrm{Na}$ redox potential. This observation suggests that the Na metal counter electrode only worked as a quasi-reference electrode, it did not correctly indicate the potential of the $\mathrm{Na}^{+} / \mathrm{Na}$ redox couple, most likely owing to the surface film formation. Similar behavior was observed for the gelled IL Na${ }^{+}$conductors for sodium batteries. ${ }^{46}$ The deposition overpotential observed in the $\mathrm{Na}[\mathrm{FSA}]-\left[\mathrm{C}_{2} \mathrm{C}_{1}\right.$ im] [FSA] IL was not observed for this ILPE, suggesting that the interfacial process occurs more smoothly in the solid state than in the liquid state, ${ }^{12}$ which may be related to the difference in the properties of surface film. Unfortunately, surface analysis of the Na metal electrode after cycle was difficult in this study because the bad condition of the electrode surface. The anodic decomposition occurs around $4.7 \mathrm{~V}$, which is comparable to the case of the $\mathrm{Na}$ [FSA]/PEO polymer electrolyte. ${ }^{26}$ Although the voltammogrametric data on a flat Pt electrode provides only preliminary anodic stability, the present result indicates the possible compatibility of ILPE-5 to many of the known positive electrode materials for $\mathrm{Na}$ secondary batteries. The $\mathrm{Al}$ working electrode 


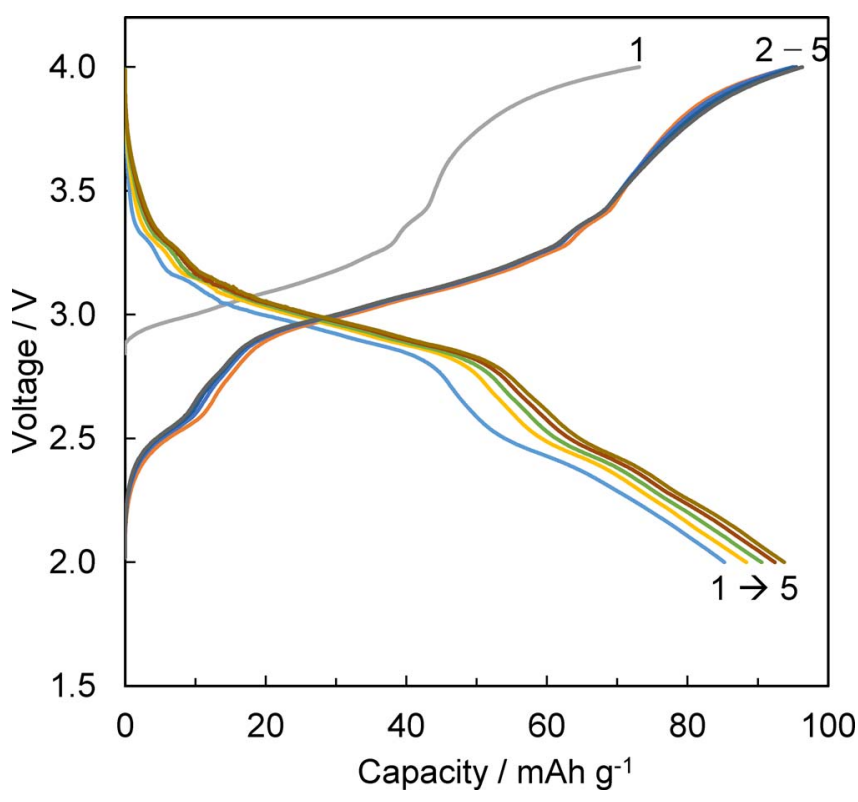

Figure 5. Galvanostatic charge-discharge curves for the Na/ILPE$5 / \mathrm{Na}_{2} \mathrm{FeP}_{2} \mathrm{O}_{7}$ cell at $363 \mathrm{~K}$. Cut-off voltage: $2.0-4.0 \mathrm{~V}$, current density: $10 \mathrm{~mA} \mathrm{~g}^{-1}$

exhibits the highest anodic stability with ILPE-5 without showing the onset of anodic current, suggesting the validity of Al current collector for positive electrodes. This is similar to the observation for the $\mathrm{Na}$ [FSA]-[C $\left.\mathrm{C}_{2} \mathrm{C}_{1} \mathrm{im}\right][\mathrm{FSA}] \mathrm{IL}$ system, and indicates the formation of passivation film on the electrode surface.

Charge-discharge behavior of $\mathrm{Na}_{2} \mathrm{FeP}_{2} \mathrm{O}_{7}$.-Figure 5 shows the galvanostatic charge-discharge curves of the Na/ILPE-5/ $\mathrm{Na}_{2} \mathrm{FeP}_{2} \mathrm{O}_{7}$ cell at $10 \mathrm{~mA} \mathrm{~g}^{-1}$ and $363 \mathrm{~K}$. The curves show a stair-case shape with a small plateau at $2.4 \mathrm{~V}$ followed by a large plateau at $2.9 \mathrm{~V}$. However, the plateaus are somewhat less clear compared to those in organic and IL electrolytes. ${ }^{35,39}$ In particular, the discharge capacity below $2.3 \mathrm{~V}$ is significantly larger than the charge capacity in the same voltage region. This difference seems to be supplemented in the voltage region above $3.5 \mathrm{~V}$. This suggests the existence of an electrode process with large reaction resistance that is absent in the liquid system. The reversible capacity increases during the consecutive cycles and reaches $92 \mathrm{mAh} \mathrm{g}^{-1}$ at the $5^{\text {th }}$ cycle, with the Coulombic efficiency of $97.3 \%$. The increase in discharge capacity probably arises from a greater extend of the impregnation of the active materials by the electrolyte. Further cycles test was not conducted in this study since the capacity of the present cell fades immediately at a higher current density. By considering the high stability of the $\mathrm{Na} / \mathrm{Na}[\mathrm{FSA}]-\mathrm{C}_{2} \mathrm{C}_{1}$ im] $[\mathrm{FSA}]-$ $\mathrm{IL} / \mathrm{Na}_{2} \mathrm{FeP}_{2} \mathrm{O}_{7}$ cell with the corresponding ionic liquid (more than 1500 cycles), ${ }^{39}$ the $\mathrm{Na} / \mathrm{ILPE}-5 / \mathrm{Na}_{2} \mathrm{FeP}_{2} \mathrm{O}_{7}$ cell is potentially stable for longer cycles. Improvement in rate capability is a future problem for this system.

\section{Conclusions}

This study reported the first PVC-based ILPE $\left[\mathrm{C}_{2} \mathrm{C}_{1}\right.$ im] [FSA]$\mathrm{Na}$ [FSA]-PVC for sodium secondary batteries. Its ionic conductivity increases with the content of $\mathrm{IL}$, reaching a maximum at $\left[\mathrm{C}_{2} \mathrm{C}_{1}\right.$ im] $[\mathrm{FSA}]: \mathrm{Na}$ [FSA]:PVC $=2.0: 1.0: 1.0 \mathrm{in} \mathrm{w/w} \mathrm{(ILPE-5).} \mathrm{The}$ combined thermogravimetry and differential scanning calorimetry analyses indicated that the ILPE thermally decomposes without melting at above $500 \mathrm{~K}$. Stable electrodeposition/dissolution of sodium metal occurred at the cathodic limit for ILPE-5, and the anodic limit on a Pt electrode was around $4.7 \mathrm{~V}$ vs. $\mathrm{Na}^{+} / \mathrm{Na}$. The discharge capacity of $92 \mathrm{mAh} \mathrm{g}^{-1}$ was obtained at $363 \mathrm{~K}$ with a $\mathrm{Na}_{2} \mathrm{FeP}_{2} \mathrm{O}_{7}$ positive electrode in the $\mathrm{Na} / \mathrm{ILPE}-5 / \mathrm{Na}_{2} \mathrm{FeP}_{2} \mathrm{O}_{7}$-cell. These results suggest the potential of the PVC-based ILPE as a solid state electrolyte for safe, reliable sodium secondary batteries.

\section{Acknowledgments}

M. A. Ab Rani thanks the Ministry of Higher Education of Malaysia for sponsorship and Prof. Ri Hanum Yahaya Subban for discussions.

\section{References}

1. M. Armand and J.-M. Tarascon, Nature, 451, 652 (2008).

2. M. R. Palacin, Chem. Soc. Rev., 38, 2565 (2009).

3. H. Pan, Y.-S. Hu, and L. Chen, Energy Environ. Sci., 6, 2338 (2013).

4. A. Ponrouch, R. Dedryvère, D. Monti, A. E. Demet, J. M. Ateba Mba, L. Croguennec, C. Masquelier, P. Johansson, and M. R. Palacín, Energy Environ. Sci., 6, 2361 (2013).

5. K. Kuratani, N. Uemura, H. Senoh, H. T. Takeshita, and T. Kiyobayashi, J. Power Sources, 223, 175 (2013)

6. J. P. Hallett and T. Welton, Chem. Rev., 111, 3508 (2011).

7. M. A. Ab Rani, A. Brant, L. Crowhurst, A. Dolan, M. Lui, N. H. Hassan, J. P. Hallett, P. A. Hunt, H. Niedermeyer, J. M. Perez-Arlandis, M. Schrems, T. Welton, and R. Wilding, Phys. Chem. Chem. Phys., 13, 16831 (2011).

8. K. Matsumoto, Y. Okamoto, T. Nohira, and R. Hagiwara, J. Phys. Chem. C., 119, 7648 (2015).

9. M. Forsyth, H. Yoon, F. Chen, H. Zhu, D. R. MacFarlane, M. Armand, and P. C. Howlett, J. Phys. Chem. C, 120, 4276 (2016).

10. K. Matsumoto, T. Hosokawa, T. Nohira, R. Hagiwara, A. Fukunaga, K. Numata, E. Itani, S. Sakai, K. Nitta, and S. Inazawa, J. Power Sources, 265, 36 (2014).

11. D. Monti, E. Jónsson, M. R. Palacín, and P. Johansson, J. Power Sources, 245, 630 (2014).

12. R. Wibowo, L. Aldous, E. I. Rogers, S. E. Ward Jones, and R. G. Compton, J. Phys. Chem. C, 114, 3618 (2010).

13. Y.-S. Ye, J. Rick, and B.-J. Hwang, J. Mater. Chem. A, 1, 2719 (2013).

14. I. Osada, H. de Vries, B. Scrosati, and S. Passerini, Angew. Chem. Int. Ed., 55, 500 (2015).

15. E. Quartarone and P. Mustarelli, Chem. Soc. Rev., 40, 2525 (2011).

16. H. de Vries, S. Jeong, and S. Passerini, RSC Adv., 5, 13598 (2015).

17. M. Wetjen, G.-T. Kim, M. Joost, G. B. Appetecchi, M. Winter, and S. Passerini, $J$. Power Sources, 246, 846 (2014).

18. M. Joost, M. Kunze, S. Jeong, M. Schönhoff, M. Winter, and S. Passerini, Electrochim. Acta, 86, 330 (2012).

19. J.-H. Shin, W. A. Henderson, and S. Passerini, J. Electrochem. Soc., 152, A978 (2005).

20. J.-H. Shin, W. A. Henderson, C. Tizzani, S. Passerini, S.-S. Jeong, and K.-W. Kim, J. Electrochem. Soc., 153, A1649 (2006)

21. J. Shin, Electrochem. Commun., 5, 1016 (2013)

22. Y. Q. Yang, Z. Chang, M. X. Li, X. W. Wang, and Y. P. Wu, Solid State Ionics, 269, $1(2015)$.

23. A. M. Stephan, K. S. Nahm, M. Anbu Kulandainathan, G. Ravi, and J. Wilson, Eur. Polym. J., 42, 1728 (2006).

24. A. Boschin and P. Johansson, Electrochim. Acta, 175, 124 (2015).

25. A. Boschin and P. Johansson, Electrochim. Acta, 211, 1006 (2016).

26. X. Qi, Q. Ma, L. Liu, Y.-S. Hu, H. Li, Z. Zhou, X. Huang, and L. Chen, ChemElectroChem, 3, 1741 (2016).

27. V. K. Singh, S. Shalu, S. K. Chaurasia, and R. K. Singh, RSC Adv., 6, 40199 (2016).

28. A. Ponrouch, D. Monti, A. Boschin, B. Steen, P. Johansson, and M. R. Palacín, J. Mater. Chem. A, 3, 22 (2015).

29. A. Fukunaga, T. Nohira, Y. Kozawa, R. Hagiwara, S. Sakai, K. Nitta, and S. Inazawa, J. Power Sources, 209, 52 (2012).

30. C. Ding, T. Nohira, K. Kuroda, R. Hagiwara, A. Fukunaga, S. Sakai, K. Nitta, and S. Inazawa, J. Power Sources, 238, 296 (2013).

31. C. Ding, T. Nohira, R. Hagiwara, K. Matsumoto, Y. Okamoto, A. Fukunaga, S. Sakai, K. Nitta, and S. Inazawa, J. Power Sources, 269, 124 (2014).

32. C. Y. Chen, K. Matsumoto, T. Nohira, and R. Hagiwara, J. Electrochem. Soc., 162 , A176 (2014).

33. C.-Y. Chen, K. Matsumoto, T. Nohira, C. Ding, T. Yamamoto, and R. Hagiwara, Electrochim. Acta, 133, 583 (2014).

34. J. M. Clark, P. Barpanda, A. Yamada, and M. S. Islam, J. Mater. Chem. A, 2, 11807 (2014).

35. P. Barpanda, T. Ye, S.-i. Nishimura, S.-C. Chung, Y. Yamada, M. Okubo, H. Zhou, and A. Yamada, Electrochem. Commun., 24, 116 (2012).

36. P. Barpanda, G. Liu, C. D. Ling, M. Tamaru, M. Avdeev, S.-C. Chung, Y. Yamada, and A. Yamada, Chem. Mater, 25, 3480 (2013).

37. H. Kim, R. A. Shakoor, C. Park, S. Y. Lim, J.-S. Kim, Y. N. Jo, W. Cho, K. Miyasaka, R. Kahraman, Y. Jung, and J. W. Choi, Adv. Funct. Mater., 23, 1147 (2013).

38. T. Honma, A. Sato, N. Ito, T. Togashi, K. Shinozaki, and T. Komatsu, J. Non-Cryst. Solids, 404, 26 (2014).

39. C.-Y. Chen, T. Kiko, T. Hosokawa, K. Matsumoto, T. Nohira, and R. Hagiwara, J. Power Sources, 332, 51 (2016).

40. S. K. Deraman, N. S. Mohamed, and S. R. H. Y, Int. J. Electrochem. Sci., 8, 1459 (2013).

41. A. M. A. Dias, S. Marceneiro, H. D. Johansen, M. M. Barsan, C. M. A. Brett, and H. C. de Sousa, RSC Adv., 6, 88979 (2016). 
42. D. Kumar and S. A. Hashmi, Solid State Ionics, 181, 416 (2010).

43. L. Li, J. Wang, P. Yang, S. Guo, H. Wang, X. Yang, X. Ma, S. Yang, and B. Wu, Electrochim. Acta, 88, 147 (2013).

44. S. Xiao, F. Wang, Y. Yang, Z. Chang, and Y. Wu, RSC Adv., 4, 76 (2014).
45. J. Serra Moreno, M. Armand, M. B. Berman, S. G. Greenbaum, B. Scrosati, and S. Panero, J. Power Sources, 248, 695 (2014).

46. S. A. Mohd Noor, H. Yoon, M. Forsyth, and D. R. MacFarlane, Electrochim. Acta 169, $376(2015)$ 